\title{
Sulfate-Reducing ElectroAutotrophs and Their Applications in Bioelectrochemical Systems
}

\author{
Valeria Agostino ${ }^{1}$ and Miriam A. Rosenbaum ${ }^{1,2,3 *}$ \\ 1 Institute of Applied Microbiology, Aachen Biology and Biotechnology, RWTH Aachen University, Aachen, Germany, ${ }^{2}$ Bio \\ Pilot Plant, Leibniz Institute for Natural Product Research and Infection Biology - Hans-Knöll-Institute, Jena, Germany, \\ ${ }^{3}$ Faculty of Biological Sciences, Friedrich Schiller University, Jena, Germany
}

\section{OPEN ACCESS}

Edited by:

Deepak Pant

Flemish Institute for Technological Research, Belgium

Reviewed by:

Mirella Di Lorenzo,

University of Bath, United Kingdom

Feng Zhao,

Institute of Urban Environment (CAS),

China

Mohita Sharma,

University of Calgary, Canada

${ }^{*}$ Correspondence:

Miriam A. Rosenbaum

miriam.rosenbaum@/eibniz-hki.de

Specialty section: This article was submitted to Bioenergy and Biofuels,

a section of the journal

Frontiers in Energy Research

Received: 03 April 2018

Accepted: 04 June 2018

Published: 20 June 2018

Citation:

Agostino $\mathrm{V}$ and Rosenbaum MA

(2018) Sulfate-Reducing

ElectroAutotrophs and Their

Applications in Bioelectrochemical

Systems. Front. Energy Res. 6:55.

doi: 10.3389/fenrg.2018.00055
Electroautotrophs are microbes able to perform different biocathodic reactions by using $\mathrm{CO}_{2}$ as sole carbon source and electrochemical reducing power as a sole energy source. Electroautotrophy has been discovered in several groups of microorganisms, including iron-oxidizing bacteria, iron-reducing bacteria, nitrate-reducing bacteria, acetogens, methanogens and sulfate-reducing bacteria. The high diversity of electroautrophs results in a wide range of Bioelectrochemical Systems (BES) applications, ranging from bioproduction to bioremediation. In the last decade, particular research attention has been devoted toward the discovery, characterization and application of acetogenic and methanogenic electroautotrophs. Less attention has been given to autotrophic sulfate-reducing microorganisms, which are extremely interesting biocatalysts for multiple BES technologies, with concomitant $\mathrm{CO}_{2}$ fixation. They can accomplish water sulfate removal, hydrogen production and, in some case, even biochemicals production. This mini-review gives a journey into electroautotrophic ability of sulfate-reducing bacteria and highlights their possible importance for biosustainable applications. More specifically, general metabolic features of autotrophic sulfate reducers are introduced. Recently discovered strains able to perform extracellular electron uptake and possible molecular mechanisms behind this electron transfer capacity are explored. Finally, BES technologies based on sulfate-reducing electroautotrophs are illustrated.

Keywords: bioelectrochemical systems, electroautotrophs, sulfate-reducing microorganisms, biocathodes, bioremediation, bioproduction

\section{INTRODUCTION}

During the last decade, much research focused toward the use of electroautotrophic microorganisms in Bioelectrochemical Systems (BES). While exoelectrogens have evolved to use extracellular insoluble minerals or electrodes as terminal electron acceptors, electroautotrophs are able to acquire energy by taking up electrons from extracellular solid compounds or electrodes, while using carbon dioxide $\left(\mathrm{CO}_{2}\right)$ as inorganic carbon source (Tremblay et al., 2017).

Electroautotrophy was first discovered in the model exoelectrogen genus Geobacter (Gregory et al., 2004; Gregory and Lovley, 2005). As the majority of exoelectrogenic biocatalysts are dissimilatory iron-reducing bacteria, researchers hypothesized that iron-oxidizing bacteria could be able to accept electrons from a cathodic electrode. Indeed, Acidithiobacillus ferrooxidans, Mariprofundus ferrooxydans PV-1, and Rhodopseudomonas palustris have been designated 
as electroautotrophs (Carbajosa et al., 2010; Summers et al., 2013; Bose et al., 2014). Moreover, the chemolithoautotrophic archea Methanococcus maripaludis and Methanobacterium-like archaeon strain IM1, isolated with metallic iron as sole electron donor, are able to perform electromethanogenesis (Lohner et al., 2014; Beese-Vasbender et al., 2015a). Several acetogenic bacteria, including Sporomusa ovata, Sporomusa silvacetica, Sporomusa sphaeroides, Sporumosa acidovorans, Sporumosa malonica, Clostridium ljungdahlii, Clostridium aceticum, and Moorella thermoacetica, can utilize the cathodic current for $\mathrm{CO}_{2}$ reduction to organic acids (Nevin et al., 2011; Aryal et al., 2017). Also, some autotrophic sulfate-reducing microorganisms (SRM) have shown the ability to consume electrons from the cathode to accomplish sulfate reduction and hydrogen $\left(\mathrm{H}_{2}\right)$ production (Rodrigues and Rosenbaum, 2014; Beese-Vasbender et al., 2015b). However, overall fairly little research has been devoted toward this last group of electroautotrophic biocatalysts.

Pioneering discoveries regarding cathodic electron consumption of SRM are related to anaerobic microbial induced corrosion (MIC) studies (Widdel, 1992). SRM can stimulate not only a chemically-influenced corrosion of iron through the production of corrosive hydrogen sulfide (Widdel, 1992), but also an electrochemical-induced corrosion by the consumption of "cathodic hydrogen" formed on iron in contact with water (von Wolzogen Kühr and van der Vlugt, 1934; Pankhania, 1988), or by directly uptaking electrons from iron (Dinh et al., 2004; Gu et al., 2009; Gu and Xu, 2010; Xu and Gu, 2011). The readers are referred to several excellent reviews on to role of SRM in MIC (Enning and Garrelfs, 2014; Anandkumar et al., 2016; Li et al., in press).

It should be noticed that early BES studies with SRM have been focused on their anodic exploitation for electricity generation and sulfate removal using organic substrates (Habermann and Pommer, 1991; Liang et al., 2013; Zheng et al., 2014). However, it was soon clarified that the production of electricity with SRM-based anodes was mainly due to the abiotic oxidation of biologically produced sulfide to elemental sulfur (Zhao et al., 2008). Consequently, sulfur-oxidizing bacteria have started to be applied in anodic oxidation processes for current generation (Sun et al., 2009; Gong et al., 2013; Lee et al., 2014; Zhang et al., 2014).

Another very recent and promising BES application of SRM is the cathodic electrofermentation of short chain organic acids into more valuable compounds as alcohols and acetone (Sharma et al., 2013a,b, 2014, 2015).

Figure 1A summarizes the application of the different metabolic capabilities of SRM in various BES. Despite these different attractive SRM-based BES technologies, the specific focus of this mini-review is to summarize the current understanding and trends in biocathodic applications of electroautotrophic SRM, using $\mathrm{CO}_{2}$ as inorganic carbon source (highlighted with a red box in Figure 1A).

\section{SULFATE REDUCING MICROORGANISMS}

SRM are a heterogeneous group of anaerobic microorganisms, widely distributed in anoxic environments with essential roles in the global cycling of carbon and sulfur (Jørgensen, 1982). Most cultured SRM belong to four bacterial (Deltaproteobacteria, Nitrospirae, Firmicutes, Thermodesulfobacteria) and two archaeal phyla (Euryarchaeota, Crenarchaeota) (Rabus et al., 2006; Muyzer and Stams, 2008). SRM have the ability to use sulfate, the most oxidized sulfur specie, as terminal electron acceptor for the oxidation of organic compounds or hydrogen in a process named dissimilatory sulfate reduction (Widdel and Hansen, 1991). This is an intracellular pathway that requires an eight-electron reaction for the reduction of sulfate to sulfide, with sulfite as intermediate. After crossing microbial membranes, sulfate is "activated" to form adenosine $5^{\prime}$-phosphosulfate (APS) by the enzyme Adenosine Triphosphate (ATP) sulfurylase (Peck, 1959). APS is then reduced to sulfite in a two-electron reaction performed by the enzyme APS reductase (AprBA) (Lampreia et al., 1994). The final step of sulfite reduction to sulfide is catalyzed by the dissimilatory sulfite reductase complex (Dsr), with the involvement of an energy-conserving membrane complex (DsrMKJOP or DsrMK) (Fike et al., 2016).

\section{Carbon Assimilation and Electron Donors}

SRM can grow on more than one hundred organic compounds, including monocarboxylic acids, dicarboxylic acids, sugars, alcohols, ketones, amino acids, aromatic compounds, and hydrocarbons (Barton and Fauque, 2009).

SRM can either perform incomplete or complete oxidation of organic compounds (Rabus et al., 2006). Incomplete oxidation of organic substrates results in the excretion of acetate as main product, due to a deficiency for the terminal oxidation of acetyl-CoA (Widdel, 1988). On the contrary, complete oxidizers degrade organic compounds to $\mathrm{CO}_{2}$, oxidizing acetate with two different pathways: a modified citric acid cycle (e.g., Desulfobacter spp., Brandis-Heep et al., 1983), or the acetyl-CoA pathway (e.g., Desulfobacterium spp., Schauder et al., 1986). Both of these groups can also utilize $\mathrm{H}_{2}$ as electron donor during sulfate reduction. Despite the prospects for chemolithoautotrophic growth on $\mathrm{H}_{2}$, most SRM require acetate in addition to $\mathrm{CO}_{2}$ for growth (Badziong et al., 1979). Nevertheless, true autotrophic growth with $\mathrm{H}_{2}$ as electron donor was discovered in some SRM (Pfennig et al., 1981; Jansen et al., 1985; Klemps et al., 1985; Brysch et al., 1987; Rozanova et al., 1988; Schauder et al., 1989). Of these facultative chemolithoautotrophic SRM all but Desulfosporosinus orientis are complete oxidizers (Brysch et al., 1987). Thereby, $\mathrm{CO}_{2}$-fixation proceeds through reverse reactions of the pathways used by SRM for acetyl-CoA oxidation during heterotrophic growth. D. hydrogenophilus assimilates $\mathrm{CO}_{2}$ via a reductive citric acid cycle (Schauder et al., 1987), while D. autotrophicum and D. orientis use the reductive acetyl-CoA pathway (Wood Ljungdahl-pathway) (Schauder et al., 1989), the only autotrophic microbial route able to simultaneously fix $\mathrm{CO}_{2}$ and yield ATP by converting acetyl-CoA to acetate (Wood et al., 1986; Fuchs, 2011). This pathway consists of two separate branches: one molecule of $\mathrm{CO}_{2}$ is reduced to carbon monoxide (CO) in the carbonyl branch and another $\mathrm{CO}_{2}$ molecule is reduced to a methyl group in the methyl branch. The acetyl$\mathrm{CoA}$ is generated from the combination of the CO and methyl group with the coenzyme A (Wood et al., 1986). Recent reviews 


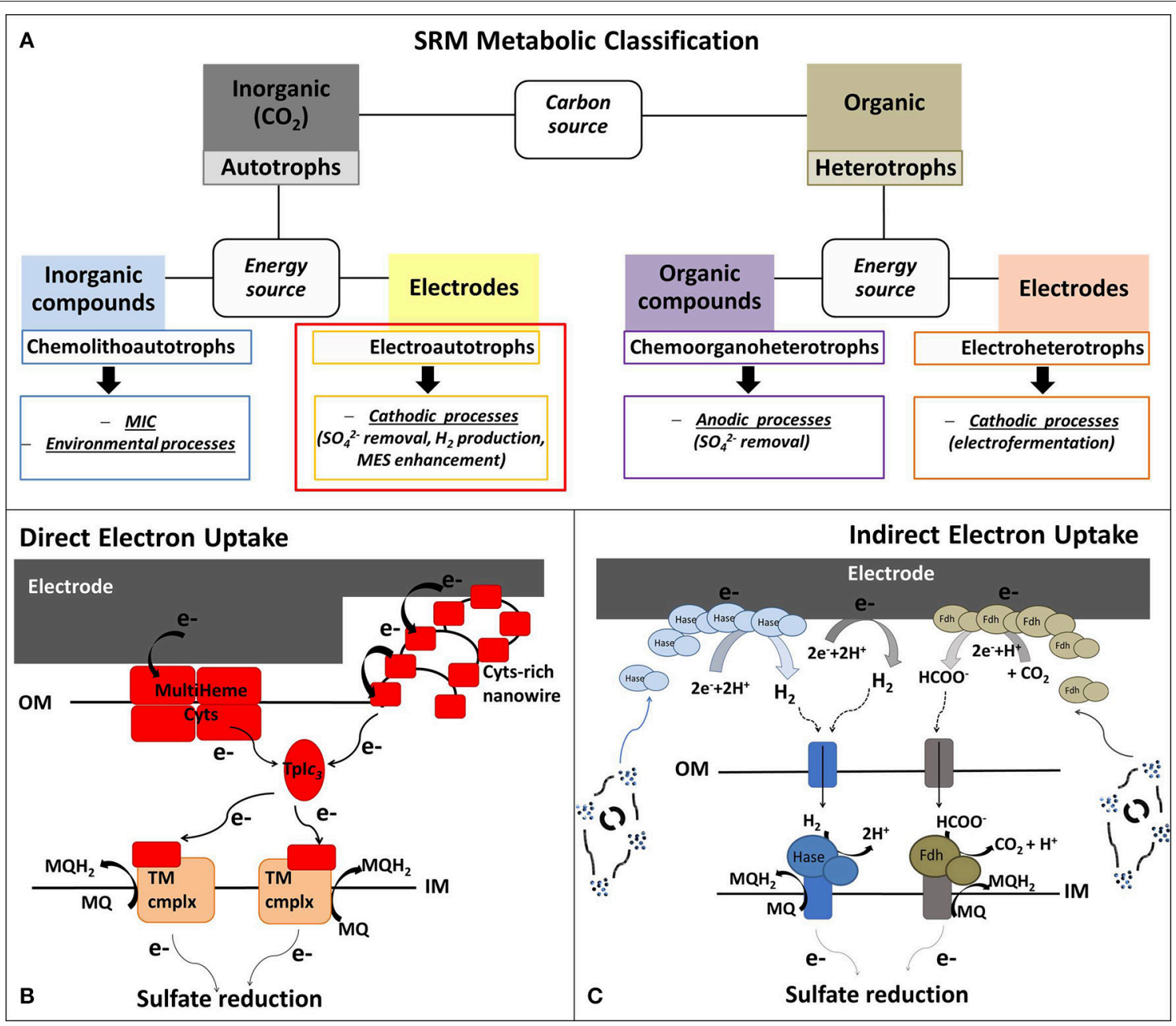

FIGURE 1 | (A) Metabolic classification of the sulfate-reducing microorganisms (SRM) presented in this Mini-Review, whereby the review focus is on electroautotrophic SRM. (B,C) Schematic model of possible extracellular electron uptake (EEU) mechanisms in electroautotrophic SRM with (B) Direct EEU: the cathodic electrons can enter SRM cells through outer membrane (OM) multiheme cytochromes (Cyts) or via Cyt-covered nanowires (Deng et al., 2018). Cyt-rich group of SRM (Deltaproteobacteria and Nitrospirae) are characterized by periplasmatic tetraheme Type I cytochrome c3 (Tplc3) that could act as periplasmatic electron shuttle component, like cytochrome Cyc-1 in A. ferroxidans (Ishii et al., 2015) and the monoheme c-Cyt PccH in Geobacter sulfurreducens (Strycharz et al., 2011). Tplc3 serves then as electron donor for several inner membrane redox complexes that reduce the menaquinone pool or are involved in transmembrane electron transfer; and (C) Indirect EEU: SRM belonging to Cyt-poor group (Archaea and Clostridia) have no periplasmatic multiheme c-Cyts and they most probably perform a mediated electron transfer, using $\mathrm{H}_{2}$ and formate as soluble electron donors for their hydrogenases (Hase) and formate dehydrogenases (Fdh) associated to the inner membrane (IM). The abiotic electrochemical production of $\mathrm{H}_{2}$ and formate can be enhanced by extracellular Hase and Fdh, excreted by viable cells or released after microbial death (Deutzmann et al., 2015). MES, Microbial electrosynthesis; MIC, microbial induced corrosion; MQ/MQH 2 , menaquinone/menaquinol; TM cmplx, transmembrane complex.

give an exhaustive biochemical description of these $\mathrm{CO}_{2}$-fixation pathways (Berg, 2011; Fuchs, 2011; Schuchmann and Müller, 2014).

\section{Energy-Conservation and Electron Transport Pathways}

In chemolithoautotrophic SRM, sulfate reduction must be coupled to energy conservation by oxidative phosphorylation. This implies an electron transport chain that allows the production of a transmembrane proton motive force for the chemiosmotic synthesis of ATP (Thauer et al., 2007; Grein et al., 2013). While APS and sulfite reduction are two strongly exoergonic reactions, the enzymes responsible, AprBA and DsrAB/DsrC, are cytoplasmic soluble reductases and, thus, cannot be directly involved in the formation of a transmembrane proton gradient. Instead, the quinone-interacting membranebound oxidoreductase complex (QmoABC) (Pires et al., 2003) and the DsrMKJOP complex (Pires et al., 2006) represent the membrane complex candidates that can act as electron donor for AprBA and DsrAB/DsrC, respectively (Ramos et al., 2012; Grein et al., 2013). Both complexes are strictly conserved across 
SRM (Pereira et al., 2011). Other energy-conserving membrane complexes, capable of ion translocation, are present in SRM, but they are less conserved (Pereira et al., 2011).

Due to the high variability of organic and inorganic electron donors used by SRM, there is no unifying theory for their electron transport chain. However, one classification method is based on the content of periplasmic c-type cytochromes (c-Cyt) (Rabus et al., 2015). The cytochromerich group has numerous multiheme $c$-Cyt and includes SRM belonging to Deltaproteobacteria (e.g., Desulfovibrio spp., Desulfobulbus spp., Desulfomicrobium spp.) and Nitrospira (e.g., Thermodesulfovibrio spp.), while the cytochrome-poor group has few or no $c$-Cyt and comprises Archaea (e.g., Archaeoglobus spp.) and Clostridia SRM (e.g., Desulfosporosinus spp., Desulfotomaculum spp.) (Pereira et al., 2011; Rabus et al., 2015). Cytochrome-rich SRM have soluble periplasmatic hydrogenases and formate dehydrogenases that lack an integral membrane subunit. These soluble enzymes use a periplasmatic multiheme $c$-Cyt, usually the tetraheme cytochrome $c 3$ (TpIc3), as electron acceptor (Louro, 2007; da Silva et al., 2012; Romaõ et al., 2012) (Figure 1B). These SRM also contain a set of inner membrane redox complexes that reduce the menaquinone pool (Qrc, Nhc and Ohc) or are involved in transmembrane electron transfer (Tmc and Hmc) (Rabus et al., 2015). On the contrary, cytochrome-poor SRM have membrane-bound hydrogenases and formate dehydrogenases associated to the inner membrane through a $b$-type cytochrome that directly reduce the menaquinone pool (Pereira et al., 2011) (Figure 1C).

\section{Electroautotrophic SRM}

The discovery of direct electron uptake capacity of some Fe(0)-corroding SRM (Dinh et al., 2004; Gu et al., 2009; Gu and $\mathrm{Xu}, 2010 ; \mathrm{Xu}$ and $\mathrm{Gu}, 2011$ ) suggested the researchers to start employing these microorganisms for biocathodic BES applications, turning, thus, this negative metabolic feature into positive and sustainable biotechnological solutions. However, so far only few pure culture SRM are elucidated as electroautotrophs.

In 2008, Desulfovibrio desulfuricans ATCC 27774 was shown to form an electroactive cathodic biofilm at an applied cathodic potential $\left(\mathrm{E}_{\mathrm{cath}}\right)$ of $-0.169 \mathrm{~V}$ vs. SHE. A stable negative current was obtained after 20 days, but lactate was supplied as carbon source, not $\mathrm{CO}_{2}$ (Cordas et al., 2008). Subsequently, other species of the genus Desulfovibrio were tested for cathodic current generation and $\mathrm{H}_{2}$ production, using bicarbonate or lactate as carbon source and $\mathrm{E}_{\text {cath }}$ that allow abiotic $\mathrm{H}_{2}$ evolution: $D$. paquesii and D. caledoniensis (Yu et al., 2011; Aulenta et al., 2012).

As first pure culture SRM to really show electroautotrophy, we identified Desulfosporosinus orientis and Desulfovibrio piger at $\mathrm{E}_{\mathrm{cath}}=-0.31 \mathrm{~V}$ vs. SHE, which is much more positive than the $\mathrm{H}_{2}$ evolution redox potential at neutral conditions $\left(\mathrm{E}_{\mathrm{H}+/ \mathrm{H} 2}^{0^{\prime}}=-0.41 \mathrm{~V}\right.$ vs. SHE$)$, with gaseous $\mathrm{CO}_{2}$ as sole inorganic growth substrate (Rodrigues and Rosenbaum, 2014). D. orientis is a spore-forming SRM in the class Clostridia and is able to perform anaerobic sulfate respiration but also acetogenesis. It can utilize a wide range of energy sources, such as $\mathrm{H}_{2} / \mathrm{CO}_{2}$, $\mathrm{CO}$, formate, lactate, pyruvate, methanol, ethanol, and medium chain fatty acids (Klemps et al., 1985; Robertson et al., 2001), and different terminal electron acceptors, such as sulfate, thiosulfate, sulfite, sulfur dioxide (Cypionka and Pfennig, 1986).

D. piger is a non-spore-forming, $\mathrm{H}_{2}$-oxidizing Gram-negative SRM Deltaproteobacterium. It can oxidize organic compounds, such as ethanol, lactate, and pyruvate, incompletely to acetate. Like for the other Desulfovibrio species, autotrophic growth on $\mathrm{CO}_{2}$ was not reported before.

Desulfopila corrodens strain IS4 is the first $\mathrm{Fe}(0)$-corroding SRM characterized in BES (Beese-Vasbender et al., 2015b). This Gram-negative Deltaproteobacterium was isolated from marine sediment using metallic iron as the sole electron donor. Using iron as energy source, this strain is able to perform very rapid sulfate reduction and hydrogen production compared to the conventional hydrogen-scavenging Desulfovibrio species (Dinh et al., 2004). In BES, direct electron uptake was achieved at $\mathrm{E}_{\text {cath }}=-0.4 \mathrm{~V}$ vs. SHE with $\mathrm{CO}_{2}$ in the headspace as carbon substrate (Beese-Vasbender et al., 2015b).

Very recently, electroautotrophic activity was reported also in the fully sequenced sulfate-reducing bacterium Desulfobacterium autotrophicum HRM2, using a $\mathrm{E}_{\text {cath }}=-0.5 \mathrm{~V}$ vs. SHE (Zaybak et al., 2018). This Deltaproteobacterium, isolated from marine mud, is a complete oxidizer SRM belonging to the $c$-Cyt rich group and harboring a bidirectional Wood-Ljungdahl pathway (Brysch et al., 1987; Strittmatter et al., 2009). D. autotrophicum HRM2 exhibited acetate bioelectrosynthesis ability, with an extremely high coulombic efficiency of $83 \pm 6 \%$ (Zaybak et al., 2018).

\section{EXTRACELLULAR ELECTRON UPTAKE IN SRM}

Little is known about the molecular mechanisms beyond extracellular electron uptake (EEU) in SRM and in electroautotrophic microorganisms in general. As for the extracellular electron transfer (EET) from microbes to the anode, direct and indirect pathways can be employed. So far, direct EEU mechanisms have been elucidated in the oxygen-reducers Shewanella oneidensis, which directly uses electrons from the cathode via the reversed anodic Mtr pathway (Ross et al., 2011), and Acidithiobacillus ferroxidans, which utilizes a cascade of outer membrane (OM) cytochrome reductases (Ishii et al., 2015). Indirect electron transfer pathway has been demonstrated for the anaerobic methanogen Methanococcus maripaludis (Choi and Sang, 2016). Here, the electron uptake seems dependent on extracellular formate dehydrogenases and hydrogenases that catalyze the cathodic production of hydrogen and formate, which act as soluble electron donors for microbial activity (Deutzmann et al., 2015).

\section{Indirect Mechanism}

Generally, in BES for bioremediation and bioproduction a power input is given to reduce cathodic potential and drive thermodynamically unfavorable bioelectrochemical reductions. If the $\mathrm{E}_{\text {cath }}$ is more negative that the standard redox potential of the $\mathrm{H}^{+} / \mathrm{H}_{2}$ couple, molecular $\mathrm{H}_{2}$ is generated at the 
cathode. The majority of acetogens, methanogens as well as SRM are able to use $\mathrm{H}_{2}$ as electron donor. Consequently, abiotic $\mathrm{H}_{2}$ can easily mediate the EET from cathode to hydrogenotrophic microorganisms. In addition, similar to the case of M. maripaludis, solubles enzymes, released by SRM after cell lysis, could increase the abiotic production rate of $\mathrm{H}_{2}$ and even formate by decreasing the overpotentials of these abiotic electroreduction processes (Figure 1C). Indeed, SRM are characterized by a high amount of soluble periplasmatic and cytoplasmatic hydrogenases and formate dehydrogenases (Rabus et al., 2006).

\section{Direct Mechanism}

As discussed above, $D$. orientis, $D$. piger, and $D$. corrodens strain IS4 have shown ability to grow in cathodic environments with applied potentials too positive for the abiotic $\mathrm{H}_{2}$ evolution, suggesting a direct EEU requiring a physical interaction between the electrode and the microbial cells (Figure 1B).

D. piger and D. corrodens strain IS4 belong to the cytochromerich group of SRM, both having the periplasmatic TpIc3, but not D. orientis (Rabus et al., 2006). Nevertheless, the OM proteins that permit the entrance of extracellular electrons inside SRM cells and the subsequent reduction of periplasmatic redox components have yet to be elucidated. Electrochemical and infrared spectroelectrochemical analyses identified $c$-Cyt as redox active components associated with the OM of D. corrodens strain IS4 and are, thus, possibly involved in direct EEU (BeeseVasbender et al., 2015b). These results are supported by the very recent study of the electron uptake mechanism of another iron-corroding SRM, Desulfovibrio ferrophilus IS5 (Deng et al., 2018). This strain was isolated from marine sediment with D. corrodens IS4 (Dinh et al., 2004). Biochemical, transcriptomic, and microscopic analyses of D. ferrophilus IS5 pointed out a high expression of different OM multiheme cytochromes in response to organic electron donor limitation. Moreover, transmission electron microscopy revealed segmented nanowire structures, strongly positive for cytochrome staining and very similar to the ones of $S$. oneidensis, suggesting that also D. ferrophilus IS5 can use nanowires for EEU (Deng et al., 2018).

\section{BES TECHNOLOGIES BASED ON ELECTROAUTOTROPHIC SRM}

With growing interest in Microbial Electrolysis Cell (MEC) (Logan and Rabaey, 2012), SRM have started to be applied in biocathodic systems. This section outlines the recent applications of electroautotrophic SRM-based biocathodes, using $\mathrm{CO}_{2}$ as inorganic carbon source.

\section{Sulfate-Rich Waters Treatment}

Sulfate-rich wastewaters require treatment before being discharged to the environment, as this anion may create acute laxative effects in humans and it may increase dissolution of metals in water resources (Gomez et al., 1995). Biological sulfate removal technologies are based on the exploitation of SRM. Sulfate-rich wastewaters are usually deficient in organic matter and, thus, external electron donors are required to achieve complete sulfate reduction in bioreactors (Liamleam and Annachhatre, 2007). While methanogens are generally more competitive to use organic electron donors, autotrophic SRM are generally more efficient in $\mathrm{H}_{2}$ utilization. However, the application of hydrogen reports several disadvantages, like cost and safety aspects of $\mathrm{H}_{2}$ storage. BES can overcome some of these limitations since the production/consumption of $\mathrm{H}_{2}$ occur in the same reactor, without $\mathrm{H}_{2}$ waste, and with operations at atmospheric temperature and pressure. Electricity-driven autotrophic sulfate-reduction has been reported by several authors (Su et al., 2012; Coma et al., 2013; Luo et al., 2014; Pozo et al., 2015, 2017a; Blázquez et al., 2017) and an overview is presented in Table 1. The first sulfate-reducing biocathode used a mixed culture originated from wastewater and at $\mathrm{E}_{\text {cath }}=-0.2 \mathrm{~V}$ vs. SHE a maximum sulfate reduction rate of $0.02 \mathrm{~g} \mathrm{~L}^{-1}$ day $^{-1}$ was achieved (Su et al., 2012). Thereafter, many studies, mostly with Desulfovibrio, have investigated different $\mathrm{E}_{\text {cath }}$, BES operation conditions cathodic electrode materials, inoculum source and start-up strategies (Table 1). To date, the highest bioelectrochemical sulfate reduction rate of $5.6 \mathrm{~g} \mathrm{~L}^{-1}$ day $^{-1}$ was obtained with a mixed microbial community collected from previous sulfate-reducing BES reactors at an $\mathrm{E}_{\text {cath }}$ of $-1.1 \mathrm{~V}$ vs. SHE (Pozo et al., 2017a).

Sulfide is the principal product of biological sulfate respiration and it may lead to significant issues such as corrosion, bad odors and human health toxicity. For real application of BES in sulfaterich water treatment, a second step of sulfide transformation to elemental sulfur should be integrated. Two recent studies have combined the bioelectroreduction of sulfate to sulfide with the recovery of elemental sulfur $\left(S^{0}\right)$ through the use of sulfuroxidizing bacteria in the anodic chamber of a separate BES, resulting in a $S^{0}$ recovery of $74 \%$ (Pozo et al., 2017b), or in the same biocathodic system by using part of the anodic-produced oxygen that partially diffuse to the cathode through the ion exchange membrane (Blázquez et al., 2016).

\section{Hydrogen Production}

$\mathrm{H}_{2}$ was the first value product generated through BES technology (Liu et al., 2005; Rozendal et al., 2006). Compared to conventional methods (dark fermentation, biophotolysis, water electrolysis and water photolysis), $\mathrm{H}_{2}$ production with MECs shows multiple advantages. Firstly, MECs can theoretically produce hydrogen with an energy input much lower than for industrial electrolyzers, $1 \mathrm{kWh} \mathrm{m}^{-3} \mathrm{H}_{2}$ (Rozendal et al., 2008) vs. 4.5-5 $\mathrm{kWh} \mathrm{m}^{-3} \mathrm{H}_{2}$ (Wang et al., 2014). Secondly, no precious metals catalysts are needed since both anodic and cathodic reactions can be catalyzed by electroactive microorganisms (Jafary et al., in press). Thirdly, cathodic biocatalysts can use the $\mathrm{CO}_{2}$ originating from organic matter as inorganic carbon source for cathodic $\mathrm{H}_{2}$ production. MEC biocathodes are usually inoculated with the effluent of running BES or by directly transferring used bioanodes or biocathodes to new cathodic chambers (Hasany et al., 2016). Microbial community analysis of several $\mathrm{H}_{2}$-producing biocathodes revealed SRM as amongst the dominant bacteria (Table 1). SRM, indeed, have an extremely high hydrogenase activity and in sulfate limitation conditions can produce $\mathrm{H}_{2}$ 
TABLE 1 | Overview of mixed-community electroautotrophic SRM-based biocathodes for sulfate removal and $\mathrm{H}_{2}$ production.

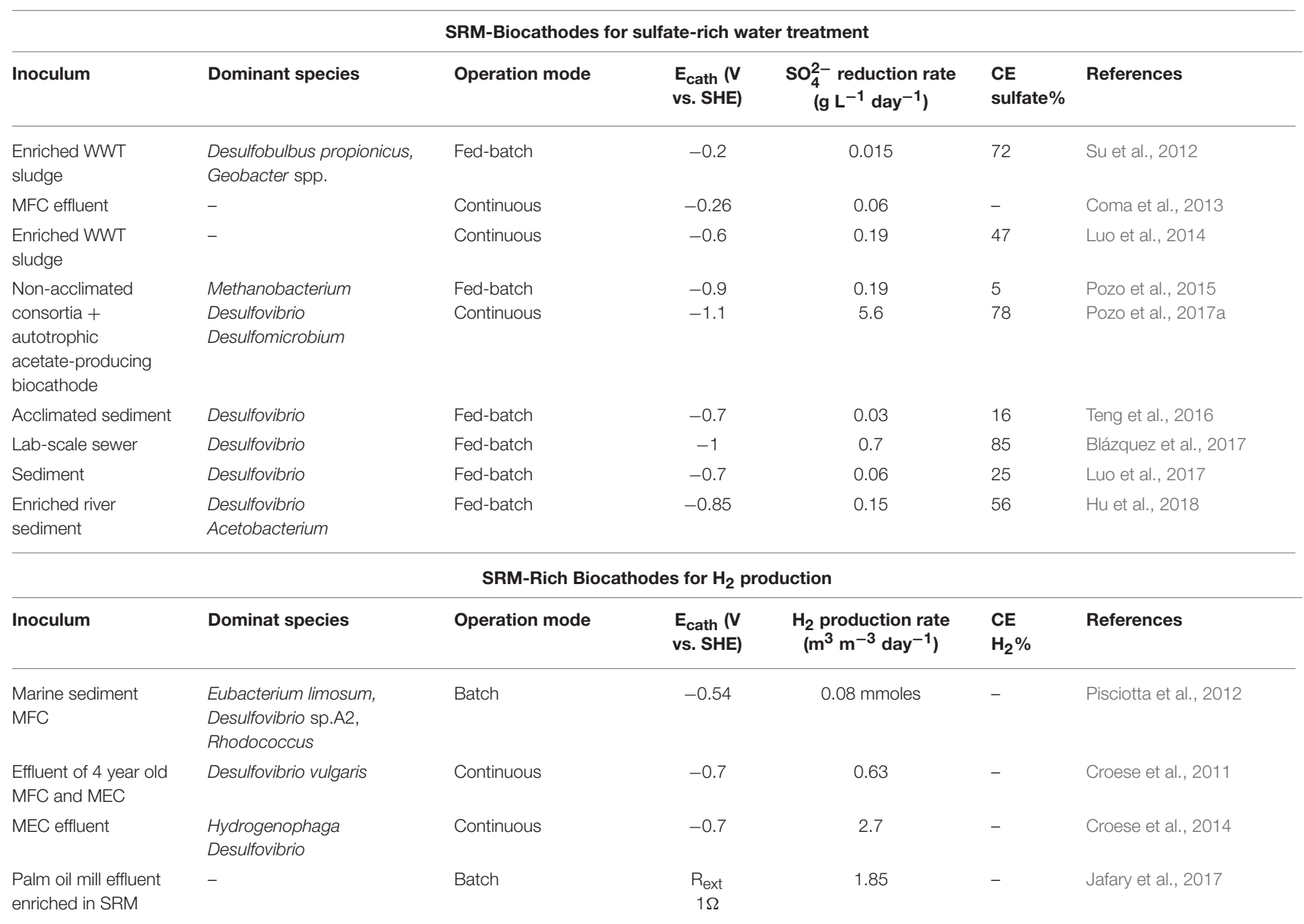

Except for the work of Jafary et al. (2017), all the BES studies reported in the table operated in MEC mode.

$C E$, coulombic efficiency; $R_{\text {ext }}$, external resistance.

fermentatively (Rabus et al., 2006). Very recently, Jafary and coworkers have purposely enriched a palm oil mill effluent sample for autotrophic SRM and then used this as inoculum source for biocathodic $\mathrm{H}_{2}$ production. The SRM enriched-biocathode was able to generate $1.85 \mathrm{~m}^{3} \mathrm{H}_{2} /\left(\mathrm{m}^{3} \cdot \mathrm{d}\right)$ in acidic catholyte conditions $(\mathrm{pH}=4)$ (Jafary et al., 2017).

It should be highlighted that the sulfate concentration in the catholyte of SRM-based MEC has to be limited not only to encourage SRM fermentative metabolism, but also to avoid the generation of a harmful off-gas mixture of $\mathrm{H}_{2} \mathrm{~S}$ and $\mathrm{H}_{2}$. Researchers should start to focus their attention on the purification of the produced $\mathrm{H}_{2}$, especially in the case of mixedcommunity biocathodes.

\section{Microbial Electrosynthesis Enhancement}

BES research on biocathodic production of alternative fuels and higher value chemicals from $\mathrm{CO}_{2}$ has caught much attention in the last years. Methane and acetate are, usually, the main products of this microbial electrosynthesis (MES), particularly in pure culture-based systems (Tremblay and Zhang, 2015). For practical implementation, the generation of molecules with higher value than acetate, such as longer carbon-chain organic compounds and alcohols, is desirable. Approaches with mixedculture MES that exploit intermediate metabolite transfer and microbial cooperation show some success to extend the product spectrum to $n$-butyrate, propionate, ethanol, isopropanol and caproate (Ganigué et al., 2015; Arends et al., 2017; Batlle-Vilanova et al., 2017; Jourdin et al., 2018). In addition, the low rate EEU of electroautotrophic acetogens and methanogens still constitute a big limit for application on a commercial scale. Especially in undefined mixed community biocathodes, high negative potentials are applied to allow $\mathrm{H}_{2}$-mediated bioproduction processes, resulting in high energetic efficiency losses.

Very recently, researchers have evaluated the enhancement of MES rates through syntrophic growth of SRM with acetogens or methanogens (Deutzmann and Spormann, 2017; Song et al., 2017; Xiang et al., 2017). By adding low concentration of sulfate in the catholyte of a MES, Xiang et al. enriched the 
biocathodic community in Desulfovibrionaceae (37\%), resulting in a 2.7 -fold increase in acetate production in comparison to a MES with lower abundance of SRM (Desulfovibrionaceae 7.3\%). As proof of concept, the Spormann group evaluated two defined co-culture biocathodes: D. corrodens strain IS4 as high rate electron uptaking and $\mathrm{H}_{2}$ producing strain was combined with Acetobacterium woodi, as acetogenic biocatalyst, or with $M$. maripaludis, as methane producer (Deutzmann and Spormann, 2017). A. woodi is not able to directly consume electrons from the cathode to produce acetate (Nevin et al., 2011), but in this case the co-culture showed acetate production rate of $0.21-0.23$ $\mu \mathrm{mol} \mathrm{cm}{ }^{-2} \mathrm{~h}^{-1}$ at $\mathrm{E}_{\text {cath }}=-0.4 \mathrm{~V}$ vs. SHE. The D. corrodens $-M$. maripaludis co-culture exhibited a methane production 20-times higher (0.6-1.2 $\mu \mathrm{mol} \mathrm{h}^{-1} \mathrm{~cm}^{-2}$ ) (Deutzmann and Spormann, 2017) compared to a pure culture $M$. maripaludis cathode poised at $-0.6 \mathrm{~V}\left(0.05 \mu \mathrm{mol} \mathrm{h}{ }^{-1} \mathrm{~cm}^{-2}\right)$ (Lohner et al., 2014). This study opens the door for the exploitation of defined co-cultures for microbial electrosynthesis of higher value chemicals from $\mathrm{CO}_{2}$. Thereby, naturally efficient electroautotrophic strains, can be coupled with acetogenic engineered strains. Importantly, this combination of an efficient cathodic EEU catalyst with an efficient bioproduction catalyst in the bulk liquid allows for a better use of the entire volume of the cathodic reactor. For the real scale-up of the MES process using SRM, researchers should consider also undesired MIC activities of these biocatalysts and, thus, avoid the use of metallic materials in the reactor design.

\section{CONCLUDING REMARKS AND OUTLOOK}

With the aim to mitigate climate change, much research efforts have been initiated toward the development of new biotechnologies able to convert $\mathrm{CO}_{2}$-rich waste gases into valuable products. MES represents one of these technologies. Thereby, the exploitation of autotrophic SRM in $\mathrm{CO}_{2}$-based cathodic bioprocesses has just begun. With this mini-review, we highlight that SRM-based biocathodes represent a very promising technology for sustainable and environmentally friendly bioremediation and bioproduction applications. Further

\section{REFERENCES}

Anandkumar, B., George, R., Maruthamuthu, S., Parvathavarthini, N., and Mudali, U. (2016). Corrosion characteristics of sulfate-reducing bacteria (SRB) and the role of molecular biology in SRB studies: an overview. Corr. Rev. 34, 41-63. doi: 10.1515/corrrev-2015-0055

Arends, J. B. A., Patil, S. A., Roume, H., and Rabaey, K. (2017). Continuous long- term electricity-driven bioproduction of carboxylates and isopropanol from $\mathrm{CO}_{2}$ with a mixed microbial community. J. CO2 Util. 20, 141-149. doi: 10.1016/j.jcou.2017.04.014

Aryal, N., Tremblay, P. L., Lizak, D. M., and Zhang, T. (2017). Performance of different Sporomusa species for the microbial electrosynthesis of acetate from carbon dioxide. Biores. Technol. 233, 184-190. doi: 10.1016/j.biortech.2017.02.128

Aulenta, F., Catapano, L., Snip, L., Villano, M., and Majone, M. (2012). Linking bacterial metabolism to graphite cathodes: electrochemical insights into the H2-producing capability of Desulfovibrio sp. Chemsuschem 5, 1080-1085. doi: $10.1002 /$ cssc.201100720 understanding and characterization of these electroautotrophic biocatalysts will enable successful realization of SRM-based BES technologies. First of all, more effort should be addressed toward the screening of other $\mathrm{Fe}(0)$-corroding strains, in order to likely discover SRM with superior EEU rate capacity. Moreover, the complete elucidation of the molecular mechanisms beyond the EEU transport chain will allow genetic and metabolic engineering of these biocatalysts for the incrementation of their natural electron uptake rate and to extend the product spectrum. From an engineering point of view, the most critical challenge to achieve the commercialization of BES technologies is the development of a cost-effective and scalable reactor design. The combination of the recovery of multiple value-added products could possibly help to cut down the implementation cost. The versatility of electroautotrophic SRM could positively contribute in accomplishing this goal. For example, the sulfide produced by SMR biocathodes can be exploited for the precipitation of heavy metals, combining, thus, the treatment of sulfate-rich wastewaters and metal-rich industrial effluents with the recovery of precious metals. Thus, with the highlighted new developments and emerging technologies the formerly considered destructive process of MIC might open new ways to biotechnological productions and environmental engineering strategies.

\section{AUTHOR CONTRIBUTIONS}

VA performed the literature search for this review and prepared the first draft of the manuscript. MR discussed the content and structure and revised the review manuscript.

\section{ACKNOWLEDGMENTS}

The authors acknowledge financial support through the Cluster of Excellence Tailor-Made Fuels from Biomass EXC 236, which is funded by the Excellence Initiative of the German federal and state governments to promote science and research at German universities.

Badziong, W., Ditter, B., and Thauer, R. K. (1979). Acetate and carbon dioxide assimilation by Desulfovibrio vulgaris (Marburg), growing on hydrogen and sulfate as sole energy source. Arch. Microbiol.123, 301-305. doi: 10.1007/BF00406665

Barton, L. L., and Fauque, G., D. (2009). Biochemistry, physiology and biotechnology of sulfate-reducing bacteria. Adv. Appl. Microbiol. 68, 41-98. doi: 10.1016/S0065-2164(09)01202-7

Batlle-Vilanova, P., Ganigué, R., Ramió-Pujol, S., Ba-eras, L., Jiménez, G., Hidalgo, M., et al. (2017). Microbial electrosynthesis of butyrate from carbon dioxide: production and extraction. Bioelectrochemistry 117, 57-64. doi: 10.1016/j.bioelechem.2017.06.004

Beese-Vasbender, P. F., Grote, J. P., Garrelfs, J., Stratmann, M., and Mayrhofer, K. (2015a). Selective microbial electrosynthesis of methane by a pure culture of a marine lithoautotrophic archaeon. Bioelectrochemistry 102, 50-55. doi: 10.1016/j.bioelechem.2014.11.004

Beese-Vasbender, P. F., Nayak, S., Erbe, A., Stratmann, M., and Mayrhofer, K. (2015b). Electrochemical characterization of direct electron uptake in electrical microbially influenced corrosion of iron by the lithoautotrophic 
SRB Desulfopila corrodens strain IS4. Electrochim. Acta 167, 321-329. doi: $10.1016 /$ j.electacta.2015.03.184

Berg, I. (2011). Ecological aspects of the distribution of different autotrophic $\mathrm{CO}_{2}$ fixation pathways. Appl. Environ. Microbiol. 77, 1925-1936. doi: 10.1128/AEM.02473-10

Blázquez, E., Gabriel, D., Baeza, J. A., and Guisasola, A. (2016). Treatment of high-strength sulfate wastewater using an autotrophic biocathode in view of elemental sulfur recovery. Water Res. 105, 395-405. doi: 10.1016/j.watres.2016.09.014

Blázquez, E., Gabriel, D., Baeza, J. A., and Guisasola, A. (2017). Evaluation of key parameters on simultaneous sulfate reduction and sulfide oxidation in an autotrophic biocathode. Water Res. 123, 301-310. doi: 10.1016/j.watres.2017.06.050

Bose, A., Gardel, E., Vidoudez, C., Parra, E., and Girguis, P. (2014). Electron uptake by iron-oxidizing phototrophic bacteria. Nat. Commun. 5:3391. doi: $10.1038 /$ ncomms4391

Brandis-Heep, A., Gebhardt, N. A., Thauer, R. K., Widdel, F., and Pfennig, N. (1983). Anaerobic acetate oxidation to $\mathrm{CO}_{2}$ by Desulfobacter postgatei. I. Demonstration of all enzymes required for the operation of the citric acid cycle. Arch. Microbiol. 136, 222-229. doi: 10.1007/BF00409849

Brysch, K., Schneider, C., Fuchs, G., and Widdel, F. (1987). Lithoautotrophic growth of sulfate-reducing bacteria, and description of Desulfobacterium autotrophicum gen. nov., sp. nov. Arch. Microbiol. 148, 264-274. doi: 10.1007/BF00456703

Carbajosa, S., Malki, M., Caillard, R., Lopez, M. F., Palomares, F. J., and Martín-Gago, J. A., et al. (2010). Electrochemical growth of Acidithiobacillus ferrooxidans on a graphite electrode for obtaining a biocathode for direct electrocatalytic reduction of oxygen. Biosens. Bioelectron. 26, 877-880. doi: 10.1016/j.bios.2010.07.037

Choi, O., and Sang, B. (2016). Extracellular electron transfer from cathode to microbes: application for biofuel production. Biotechnol. Biofuels 9:11. doi: 10.1186/s13068-016-0426-0

Coma, M., Puig, S., Pous, N., Balaguer, M. D., and Colprim, J. (2013). Biocatalysed sulphate removal in a BES cathode. Bioresour. Technol. 130, 218-223. doi: 10.1016/j.biortech.2012.12.050

Cordas, C., Guerra, L., Xavier, C., and Moura, J. (2008). Electroactive biofilms of sulphate reducing bacteria. Electrochim. Acta 54, 29-34. doi: 10.1016/j.electacta.2008.02.041

Croese, E., Jeremiasse, A. W., Marshall, I. P., Spormann, A. M., Euverink, G. J. W.,Geelhoed, J. S., et al. (2014). Influence of setup and carbon source on the bacterial community of biocathodes in microbial electrolysis cells. Enzyme Microb. Technol. 61-62, 67-75. doi: 10.1016/j.enzmictec.2014.04.019

Croese, E., Pereira, M., Euverink, G. J. W., Stams, A. M., and Geelhoed, J. S. (2011). Analysis of the microbial community of the biocathode of a hydrogen-producing microbial electrolysis cell. Appl. Microbiol. Biotechnol. 92, 1083-1093. doi: 10.1007/s00253-011-3583-x

Cypionka, H., and Pfennig, N. (1986). Growth yields of Desulfotomaculum orientis with hydrogen in chemostat culture. Arch. Microbiol. 143, 396-399. doi: 10.1007/BF00412808

da Silva, S. M., Pacheco, I., and Pereira, I. A. C. (2012). Electron transfer between periplasmic formate dehydrogenase and cytochromes $\mathrm{c}$ in Desulfovibrio desulfuricans ATCC 27774. J. Biol. Inorg. Chem. 17, 831-838. doi: 10.1007/s00775-012-0900-5

Deng, X., Dohmae, N., Nealson, K., Hashimoto, K., and Okamoto, A. (2018). Multi-heme cytochromes provide a pathway for survival in energy-limited environments. Sci. Adv. 4:eaao5682. doi: 10.1126/sciadv.aao5682

Deutzmann, J. S., and Spormann, A. M. (2017). Enhanced microbial electrosynthesis by using defined co-cultures. ISME J. 11, 704-714. doi: 10.1038/ismej.2016.149

Deutzmann, J. S., Sahin, M., and Spormann, A. (2015). Extracellular enzymes facilitate electron uptake in biocorrosion and bioelectrosynthesis. mBio 6:e00496-e00415. doi: 10.1128/mBio.00496-15

Dinh, H., Kuever, J., Mußmann, M., Hassel, A., Stratmann, M., and Widdel, F. (2004). Iron corrosion by novel anaerobic microorganisms. Nature, 427, 829-832. doi: 10.1038/nature02321

Enning, D., and Garrelfs, J. (2014). Corrosion of iron by sulfate-reducing bacteria: new views of an old problem. Appl. Environ. Microbiol. 80, 1226-1236. doi: 10.1128/AEM.02848-13
Fike, D. A., Bradley, A. S., and Leavitt, W. D. (2016). "Geomicrobiology of sulfur," in Ehrlich's Geomicrobiology, 6th Edn. eds H. L. Ehrlich, D. K. Newman and A. Kappler (Boca Raton, FL: Taylor \& Francis), 479-515.

Fuchs, G. (2011). Alternative pathways of carbon dioxide fixation: insights into the early evolution of life? Annu. Rev. Microbiol. 65, 631-658. doi: 10.1146/annurev-micro-090110-102801

Ganigué, R., Puig, S., Batlle-Vilanova, P., Balaguer, M. D., and Colprim, J. (2015). Microbial electrosynthesis of butyrate from carbon dioxide. Chem. Commun. 51, 3235-3238. doi: 10.1039/C4CC10121A

Gomez, G. G., Sandler, R. S., and Seal, E. J. (1995). High levels of inorganic sulfate cause diarrhea in neonatal piglets. J. Nutr. 125, 2325-2332. doi: $10.1093 /$ jn/125.9.2325

Gong, Y., Ebrahim, A., Feist, A., Embree, M., Zhang, T., Lovley, D., et al. (2013). Sulfide-driven microbial electrosynthesis. Environ. Sci. Technol. 47, 568-573. doi: $10.1021 /$ es303837j

Gregory, K., and Lovley, D. (2005). Remediation and recovery of uranium from contaminated subsurface environments with electrodes. Environ. Sci. Technol. 39, 8943-8947. doi: 10.1021/es050457e

Gregory, K., Bond, D., and Lovley, D. (2004). Graphite electrodes as electron donors for anaerobic respiration. Environ. Microbiol. 6, 596-604. doi: 10.1111/j.1462-2920.2004.00593.x

Grein, F., Ramos, A. R., Venceslau, S. S., and Pereira, I. A. (2013). Unifying concepts in anaerobic respiration: insights from dissimilatory sulfur metabolism. Biochim. Biophys. Acta 1827, 145-160. doi: 10.1016/j.bbabio.2012.09.001

Gu, T., and Xu, D. (2010). Demystifying MIC mechanisms. Corrosion/2010, NACE International, PaperNo. 10213. Houston, TX.

Gu, T., Zhao, K., and Nesic, S. (2009). A new mechanistic model for MIC based on a biocatalytic cathodic sulfate reduction theory. Corrosion/2009, NACE International, Atlanta, Georgia, 2009, Paper No. 09390.

Habermann, W., and Pommer, E. (1991). Biological fuel cells with sulphide storage capacity. Appl. Microbiol. Biotechnol. 35, 128-133. doi: 10.1007/BF00180650

Hasany, M., Mardanpour, M., and Yaghmaei, S. (2016). Biocatalysts in microbial electrolysis cells: a review. Int. J. Hydrogen Energ. 41, 1477-1493. doi: 10.1016/j.ijhydene.2015.10.097

Hu, J., Zeng, C., Liu, G., Luo, H., Qu, L., and Zhang, R. (2018). Magnetite nanoparticles accelerate the autotrophic sulfate reduction in biocathode microbial electrolysis cells. Biochem. Eng. J. 133, 96-105. doi: 10.1016/j.bej.2018.01.036

Ishii, T., Kawaichi, S., Nakagawa, H., Hashimoto, K., and Nakamura, R. (2015). From chemolithoautotrophs to electrolithoautotrophs: $\mathrm{CO}_{2}$ fixation by $\mathrm{Fe}(\mathrm{II})$ oxidizing bacteria coupled with direct uptake of electrons from solid electron sources. Front. Microbiol. 6:994. doi: 10.3389/fmicb.2015.00994

Jafary, T., Daud, W., Ghasemi, M., Kim, B., Carmona-Martínez, A., and Bakar, M., et al. (2017). A comprehensive study on development of a biocathode for cleaner production of hydrogen in a microbial electrolysis cell. J. Clean. Prod. 164, 1135-1144. doi: 10.1016/j.jclepro.2017.07.033

Jafary, T., Wan Daud, W., Ghasemi, M., Abu Bakar, M., Sedighi, M., and Kim, B., et al. (in press). Clean hydrogen production in a full biological microbial electrolysis cell. Int. J. Hydrogen Energ. doi: 10.1016/j.ijhydene.2018.01.010

Jansen, K., G., Fuchs, and R. K., Thauer (1985). Autotrophic $\mathrm{CO}_{2}$ fixation by Desulfovibrio baarsii: demonstration of enzyme activities characteristics for the acetyl-CoA pathway. FEMS Microbiol. Lett. 28, 311-315. doi: 10.1111/j.1574-6968.1985.tb00812.x

Jørgensen, B. (1982). Mineralization of organic matter in the sea bed-the role of sulphate reduction. Nature 296, 643-645. doi: 10.1038/296643a0

Jourdin, L., Raes, S. M. T., Buisman, C. J. N., and Strik, D. P. B. T. B. (2018). Critical biofilm growth throughout unmodified carbon felts allows continuous bioelectrochemical chain elongation from $\mathrm{CO}_{2}$ up to caproate at high current density. Front. Energ. Res. 6:7. doi: 10.3389/fenrg.2018.00007

Klemps, R., Cypionka, H., Widdel, F., and Pfennig, N. (1985). Growth with hydrogen, and further physiological characteristics of Desulfotomaculum species. Arch. Microbiol. 143, 203-208. doi: 10.1007/BF00411048

Lampreia, J., Pereira, A. S., and Moura, J. J. G. (1994). “Adenylsulfate reductases from sulfate-reducing bacteria," in Methods in Enzymology, Vol. 243. eds H. D. Peck, Jr., and J. LeGall (San Diego,CA: Academic Press), 241-260.

Lee, D. J., Liu, X., and Weng, H. L. (2014). Sulfate and organic carbon removal by Microbial Fuel Cell with sulfate-reducing bacteria and 
sulfide-oxidising bacteria anodic biofilm. Bioresour. Technol. 156, 14-19. doi: 10.1016/j.biortech.2013.12.129

Li, Y., Xu, D., Chen, C., Li, X., Jia, R., Zhang, D., et al. (in press). Anaerobic microbiologically influenced corrosion mechanisms interpreted using bioenergetics and bioelectrochemistry: a review. J. Mater. Sci. Technol. doi: 10.1016/j.jmst.2018.02.023

Liamleam, W., and Annachhatre, A. P. (2007). Electron donors for biological sulfate reduction. Biotechnol. Adv. 25, 452-463. doi: 10.1016/j.biotechadv.2007.05.002

Liang, F., Xiao, Y., and Zhao, F. (2013). Effect of $\mathrm{pH}$ on sulfate removal from wastewater using a bioelectrochemical system. Chem. Eng. J. 218, 147-153. doi: 10.1016/j.cej.2012.12.021

Liu, H., Grot, S., and Logan, B. E. (2005). Electrochemically assisted microbial production of hydrogen from acetate. Environ. Sci. Technol. 39, 4317-4320. doi: 10.1021/es050244p

Logan, B. E., and Rabaey, K. (2012). Conversion of wastes into bioelectricity and chemicals by using microbial electrochemical technologies. Science 337, 686-690. doi: 10.1126/science. 1217412

Lohner, S. T., Deutzmann, J. S., Logan, B. E., Leigh, J., and Spormann, A. M.(2014). Hydrogenase-independent uptake and metabolism of electrons by the archaeon Methanococcus maripaludis. ISME J. 8, 1673-1681. doi: 10.1038/ismej.2014.82

Louro, R. O. (2007). Proton thrusters: overview of the structural and functional features of soluble tetrahaem cytochromes c3. J. Biol. Inorg. Chem. 12, 1-10. doi: 10.1007/s00775-006-0165-y

Luo, H., Fu, S., Liu, G., et al. (2014). Autotrophic biocathode for high efficient sulfate reduction in microbial electrolysis cells. Bioresour. Technol. 167, 462-468. doi: 10.1016/j.biortech.2014.06.058

Luo, H., Teng, W., Liu, G., Zhang, R., and Lu, Y. (2017). Sulfate reduction and microbial community of autotrophic biocathode in response to acidity. Process Biochem. 54, 120-127. doi: 10.1016/j.procbio.2016.1 2.025

Muyzer, G., and Stams, A. (2008). The ecology and biotechnology of sulphatereducing bacteria. Nat. Rev. Microbiol. 6, 441-454. doi: 10.1038/nrmicro1892

Nevin, K. P., Hensley, S., Franks, A., Summers, Z., Ou, J., Woodard, T., et al. (2011). Electrosynthesis of organic compounds from carbon dioxide is catalyzed by a diversity of acetogenic microorganisms. Appl. Environ. Microbiol. 77, 2882-2886. doi: 10.1128/AEM. 02642-10

Pankhania, I. P. (1988). Hydrogen metabolism in sulphate-reducing bacteria and its role in anaerobic corrosion. Biofouling 1, 27-47. doi: 10.1080/08927018809378094

Peck, H. (1959). The ATP-dependent reduction of sulfate with hydrogen in extracts of Desulfovibrio desulfuricans. Proc. Natl. Acad. Sci. 45, 701-708. doi: 10.1073/pnas.45.5.701

Pereira, I. A., Ramos, A. R., Grein, F., Marques, M. C., da Silva, S. M., and Venceslau, S. S. (2011). A comparative genomic analysis of energy metabolism in sulfate reducing bacteriaand archaea. Front. Microbiol. 2:69. doi: $10.3389 /$ fmicb. 2011.00069

Pfennig, N., Widdel, F., and Trüper, H. G. (1981). "The dissimilatory sulfatereducing bacteria," in The Prokaryotes: aHandbook of Habitats, Isolation and Identification of Bacteria, eds M.P. Starr, H. Stolp, H. G. Trüper, A. Balows, and H.Schlegel (Berlin: Springer) 926-940.

Pires, R. H., Lourenço, A. I. C., Morais, F., Teixeira, M., Xavier, A. V., Saraiva, L. M., et al. (2003). A novel membrane-bound respiratory complex from Desulfovibrio desulfuricans ATCC 27774. Biochim. Biophys. Acta 1605, 67-82. doi: 10.1016/S0005-2728(03)00065-3

Pires, R. H., Venceslau, S. S., Morais, F., Teixeira, M., Xavier, A. V., and Pereira, I. A. (2006). Characterization of the Desulfovibrio desulfuricans ATCC 27774 DsrMKJOP complex-A membrane-bound redox complex involved in the sulfate respiratory pathway. Biochemistry 45, 249-262. doi: 10.1021/bi05 15265

Pisciotta, J. M., Zaybak, Z., Call, D. F., Nam, J. Y., and Logan, B. E. (2012). Enrichment of microbial electrolysis cell biocathodes from sediment microbial fuel cell bioanodes. Appl. Environ. Microbiol. 78, 5212-5219. doi: 10.1128/AEM.00480-12

Pozo, G., Jourdin, L., Lu, Y., et al. (2015). Methanobacterium enables high rate electricity-driven autotrophic sulfate reduction. RSC Adv. 5, 89368-89374. doi: 10.1039/C5RA18444D
Pozo, G., Lu, Y., Pongy, S., Keller, J., Ledezma, P., and Freguia, S. (2017a). Selective cathodic microbial biofilm retention allows a high current-to-sulfide efficiency in sulfate-reducing microbial electrolysis cells. Bioelectrochemistry 118, 62-69. doi: 10.1016/j.bioelechem.2017.07.001

Pozo, G., Pongy, S., Keller, J., Ledezma, P., and Freguia, S. (2017b). A novel bioelectrochemical system for chemical-free permanent treatment of acid mine drainage. Water Res. 126, 411-420. doi: 10.1016/j.watres.2017.09.058

Rabus, R., Hansen, T., and Widdel, F. (2006). "Dissimilatory sulfate- and sulfurreducing Prokaryotes," in The Prokaryotes, Vol. 2. eds M. Dworkin, S. Falkow, E. Rosenberg, K. H. Schleifer, and E. Stackebrandt (New York, NY: SpringerVerlag) 659-768.

Rabus, R., Venceslau, S., Wöhlbrand, L., Voordouw, G., Wall, J., and Pereira, I. (2015). A post-genomic view of the ecophysiology, catabolism and biotechnological relevance of sulphate-reducing prokaryotes. Adv. Microb. Physiol. 66, 55-321. doi: 10.1016/bs.ampbs.2015.05.002

Ramos, A. R., Keller, K. L., Wall, J. D., and Pereira, I. A. C. (2012). The membrane QmoABC complex interacts directly with the dissimilatory adenosine 5'phosphosulfate reductase in sulfate reducing bacteria. Front. Microbiol. 3:137. doi: 10.3389/fmicb.2012.00137

Robertson, W., Bowman, J., Mee, B., and Franzmann, P. (2001). Desulfosporosinus meridiei sp. nov., a spore-forming sulfate-reducing bacterium isolated from gasolene-contaminated groundwater. Int. J. Syst. Evol. Microbiol. 51, 133-140. doi: 10.1099/00207713-51-1-133

Rodrigues, T., d, C., and Rosenbaum, M. (2014). Microbial electroreduction: screening for new cathodic biocatalysts. Chemelectrochem 1, 1916-1922. doi: 10.1002/celc.201402239

Romaõ, C. V., Archer, M., Lobo, S. A., Louro, R. O., Pereira, I. A. C., Saraiva, L. M., et al. (2012). "Diversity of heme proteins in sulfate reducing bacteria," in Handbook of Porphyrin Science, Vol. 19. eds K. M. Kadish, K. M. Smith, and R. Guilard (Singapore: World Scientific Publishing Co), 139-230.

Ross, D. E., Flynn, J. M., Baron, D. B., Gralnick, J. A., and Bond, D. R. (2011). Towards electrosynthesis in Shewanella: energetics of reversing the Mtr Pathway for reductive metabolism. PLoS ONE 6:e16649. doi: 10.1371/journal.pone.00 16649

Rozanova, E. P., Nazina, T. N., and Galushko, A. S. (1988). Isolation of a new genus of sulfate-reducing bacteria and description of a new species of this genus, Desulfomicrobium apsheronum gen. nov., sp. nov. Mikrobiologiya 57, 634-641.

Rozendal, R. A., Hamelers, H. V. M., Euverink, G. J. W., Metz, S. J., and Buisman, C. J. (2006). Principle and perspectives of hydrogen production through biocatalyzed electrolysis. Int. J. Hydrogen Energ. 31, 1632-1640. doi: 10.1016/j.ijhydene.2005.12.006

Rozendal, R. A., Jeremiasse, A. W., Hamelers, H. V., and Buisman, C. J. (2008). Hydrogen production with a microbial biocathode. Environ. Sci. Technol. 42, 629-634. doi: 10.1021/es071720+

Schauder, R., Eikmanns, B., Thauer, T. K., Widdel, F., and Fuchs, G. (1986). Acetate oxidation to $\mathrm{CO}_{2}$ in anaerobic bacteria via a novel pathway not involving reactions of the citric acid cycle. Arch. Microbiol. 145, 162-172. doi: 10.1007/BF00446775

Schauder, R., Preuß, A., Jetten, M., and Fuchs, G. (1989). Oxidative and reductive acetyl CoA/carbon monoxide dehydrogenase pathway in Desulfobacterium autotrophicum. Arch. Microbiol. 151,84-89. doi: 10.1007/BF00444674

Schauder, R., Widdel, F., and Fuchs, G. (1987). Carbon assimilation pathways in sulfate-reducing bacteria. II. Enzymes of a reductive citric acid cycle in the autotrophic Desulfobacter hydrogenophilus. Arch. Microbiol. 148, 218-225. doi: $10.1007 / \mathrm{BF} 00414815$

Schuchmann, K., and Müller, V. (2014). Autotrophy at the thermodynamic limit of life: a model for energy conservation in acetogenic bacteria. Nat. Rev. Microbiol. 12, 809-821. doi: 10.1038/nrmicro3365

Sharma, M., Aryal, N., Sarma, P., Vanbroekhoven, K., Lal, B., Benetton, X., et al. (2013a). Bioelectrocatalyzed reduction of acetic and butyric acids via direct electron transfer using a mixed culture of sulfate-reducers drives electrosynthesis of alcohols and acetone. Chem. Commun. 49:6495. doi: $10.1039 /$ c3cc42570c

Sharma, M., Jain, P., Varanasi, J., Lal, B., Rodríguez, J., Lema, J., et al. (2013b). Enhanced performance of sulfate reducing bacteria based biocathode using stainless steel mesh on activated carbon fabric electrode. Bioresour. Technol. 150, 172-180. doi: 10.1016/j.biortech.2013.09.069 
Sharma, M., Sarma, P., Pant, D., and Dominguez-Benetton, X. (2015). Optimization of electrochemical parameters for sulfate-reducing bacteria (SRB) based biocathode. RSC Adv. 5, 39601-39611. doi: 10.1039/C5RA04120A

Sharma, M., Varanasi, J., Jain, P., Dureja, P., Lal, B., Dominguez-Benetton, X., et al. (2014). Influence of headspace composition on product diversity by sulphate reducing bacteria biocathode. Bioresour. Technol. 165, 365-371. doi: 10.1016/j.biortech.2014.03.075

Song, T., Fei, K., Zhang, H., Yuan, H., Yang, Y., Ouyang, P., et al. (2017). High efficiency microbial electrosynthesis of acetate from carbon dioxide using a novel graphene-nickel foam as cathode. J. Chem. Technol. Biotechnol. 93, 457-466. doi: 10.1002/jctb.5376

Strittmatter, A. W., Liesegang, H., Rabus, R., Decker, I., Amann, J., Andres, S., et al. (2009). Genome sequence of Desulfobacterium autotrophicum HRM2, a marine sulfate reducer oxidizing organic carbon completely to carbon dioxide. Environ. Microbiol. 11, 1038-1055. doi: 10.1111/j.1462-2920.2008.01825.x

Strycharz, S., Glaven, R., Coppi, M., Gannon, S., Perpetua, L., Liu, A., et al. (2011). Gene expression and deletion analysis of mechanisms for electron transfer from electrodes to Geobacter sulfurreducens. Bioelectrochemistry 80, 142-150. doi: 10.1016/j.bioelechem.2010.07.005

Su, W., Zhang, L., Tao, Y., Zhan, G., Li, D., and Li, D. (2012). Sulfate reduction with electrons directly derived from electrodes in bioelectrochemical systems. Electrochem. Commun. 22, 37-40. doi: 10.1016/j.elecom.2012.04.030

Summers, Z. M., Gralnick, J. A., and Bond, D. R. (2013). Cultivation of an obligate $\mathrm{Fe}(\mathrm{II})$-oxidizing lithoautotrophic bacterium using electrodes. mBio 4:e00420-12-e00420-12. doi: 10.1128/mBio.00420-12

Sun, M., Mu, Z., Chen, Y., Sheng, G., Liu, X., Chen, Y., et al. (2009). Microbeassisted sulfide oxidation in the anode of a microbial fuel cell. Environ. Sci. Technol. 43, 3372-3377. doi: 10.1021/es802809m

Teng, W., Liu, G., Luo, H., Zhang, R., and Xiang, Y. (2016). Simultaneous sulfate and zinc removal from acid wastewater using an acidophilic and autotrophic biocathode. J. Hazard. Mater. 304, 159-116. doi: 10.1016/j.jhazmat.2015.10.050

Thauer, R. K., Stackebrandt, E., and Hamilton, W. A. (2007). "Energy metabolism and phylogenetic diversity of sulphate-reducing bacteria," in Sulphate-Reducing Bacteria: Environmental and Engineered Systems, eds L. L. Barton and W. A. Hamilton (Cambridge: Cambridge University Press), 1-37.

Tremblay, P. L., and Zhang, T. (2015). Electrifying microbes for the production of chemicals. Front. Microbiol. 6:201. doi: 10.3389/fmicb.2015.00201

Tremblay, P. L., Angenent, L. T., and Zhang, T. (2017). Extracellular electron uptake: among autotrophs and mediated by surfaces. Trends Biotechnol. 35, 360-371. doi: 10.1016/j.tibtech.2016.10.004

von Wolzogen Kühr, C. A. H., and van der Vlugt, L. S. (1934). The graphitization of cast iron as an electrobiochemical process in anaerobic soil. Water 18,147-165.

Wang, M., Wang, Z., Gong, X., and Guo, Z. (2014). The intensification technologies to water electrolysis for hydrogen production - a review. Renew. Sustain. Energ. Rev. 29, 573-588. doi: 10.1016/j.rser.2013.08.090

Widdel, F. (1988). "Microbiology and ecology of sulphate-reducing bacteria," in Biology of Anaerobic Microorganisms, ed A. J. B. Zehnder (Munich: Carl Hanser Verlag), 469-585.
Widdel, F. (1992). "Microbial corrosion," in Biotechnology Focus, Vol. 3, eds R. K. Finn, P. Prave, M. Schlingmann, W. Crueger, K. Esser, R. Thauer and F. Wagner (Munich: Carl Hanser Verlag), 277-318.

Widdel, F., and Hansen, T. A. (1991). "The sulphate and sulphur-reducing prokaryotes," in The Prokaryotes, 2nd ed. Vol. 2, eds M. Dworkin, S. Falkow, E. Rosenberg, K.H. Schleifer, and E. Stackebrandt (New York, NY: Springer), 583-624.

Wood, H. G., Ragsdale, S. W., and Pezacka, E. (1986). The acetyl-CoA pathway of autotrophic growth. FEMS Microbiol. Rev. 39, 345-362. doi: 10.1111/j.1574-6968.1986.tb01865.x

Xiang, Y., Liu, G., Zhang, R., Lu, Y., and Luo, H. (2017). Acetate production and electron utilization facilitated by sulfate-reducing bacteria in a microbial electrosynthesis system. Bioresour. Technol. 241, 821-829. doi: 10.1016/j.biortech.2017.06.017

$\mathrm{Xu}, \mathrm{D}$., and Gu, T. (2011). Bioenergetics explains when and why more severe MIC pitting by SRB can occur. Corrosion/2011, NACE International, Houston, Texas, 2011, Paper No. 11426.

Yu, L., Duan, J., Zhao, W., Huang, Y., and Hou, B. (2011). Characteristics of hydrogen evolution and oxidation catalyzed by Desulfovibrio caledoniensis biofilm on pyrolytic graphite electrode. Electrochim. Acta 56, 9041-9047. doi: 10.1016/j.electacta.2011.05.086

Zaybak, Z., Logan, B. E., and Pisciotta, J. (2018). Electrotrophic activity and electrosynthetic acetate production by Desulfobacterium autotrophicum HRM2. Bioelectrochemistry 123, 150-155. doi: 10.1016/j.bioelechem.2018.04.019

Zhang, T., Bain, T., Barlett, M., Dar, S., Snoeyenbos-West, O., Nevin, K., et al. (2014). Sulfur oxidation to sulfate coupled with electron transfer to electrodes by Desulfuromonas strain TZ1. Microbiology 160, 123-129. doi: 10.1099/mic.0.069930-0

Zhao, F., Rahunen, N., Varcoe, J., Chandra, A., Avignone-Rossa, C., Thumser, A., et al. (2008). Activated carbon cloth as anode for culfate removal in a microbial fuel cell. Environ. Sci. Technol. 42, 4971-4976. doi: 10.1021/es8003766

Zheng, Y., Xiao, Y., Yang, Z., Wu, S., Xu, H., Liang, F., et al. (2014). The bacterial communities of bioelectrochemical systems associated with the sulfate removal under different pHs. Process Biochem. 49, 1345-1351. doi: $10.1016 /$ j.procbio.2014.04.019

Conflict of Interest Statement: The authors declare that the research was conducted in the absence of any commercial or financial relationships that could be construed as a potential conflict of interest.

Copyright (C) 2018 Agostino and Rosenbaum. This is an open-access article distributed under the terms of the Creative Commons Attribution License (CC $B Y)$. The use, distribution or reproduction in other forums is permitted, provided the original author(s) and the copyright owner are credited and that the original publication in this journal is cited, in accordance with accepted academic practice. No use, distribution or reproduction is permitted which does not comply with these terms. 